T D M BUILETIN

Juzy 1955
Vol. III

No: 7

\title{
MINING ACTIVITIES
}

FIRST DIVISION - The big news of the year to date is that comercial grade uianiumbearing materlal has finally been discovered in Alaska. The arca as found thus far is linfted and no tonnages have been blocked out (contrary to what some newspapers are reporting) but the grade 1 definitely commerctal. The actual alscovery of tile radioactive mineral wa made in May by Jan and Don Ross, a husband and wife team, Plying aerial recommalssance with a Nucliometer instrument mounted in a Piper Cub alrcraft. Acting on e strong aerial anomaly, the Rosses landed and staked the first cleim. Another husband and wife team, Judy and Kelly Adams were flown to the area. situated near the southeri end of Prince of Wales Island, where they apeut a number of doys setting up a camp, conducting radiametric groind surveys, staking claims, blazing tralls, etc. The Rosses assisted also in this later ground work. At the request of the discoverers, TDM personnel investigated the area, and found it to be very promising. A Colorado uranium canpany was then contacted by the discoverers, engineers were sent to the property, and $a$ deal is now pending. The discovery (actually one of about four or five known occurrences of uranium minerals id Southeastern Alaska) adds further encouragement to the bellef that comercial uranium production w1Il eventually take place in the Territory.

American Metal Company, a multi-milion dollar minting firm, has filed corporation papers to do business in Alaska, raving Juneeu as their principal office.

SECOND DIVISION .. The Northern Mining Co. is operating the Lomen Brothers dredge at Councll this year.

Bill Munz has moved a small dredge froin California Creek to Eldorado Creek (Bluff area) and will operate there this year.

Kotzebue.

Prospecting interest is runing at a high pitch omong the people at

THIRD DIVISION - W. E. Dunkle and the Alasks Explorat1on and Develpment Corporat1 on plan an extensive exploratory arilling progran starting in July to determine the extent of cosl beds at Dunkle"s property at Broad Pe6s on the Alaska Ra1lroad. The area to be investigeted comprises over 1000 acres and it is expected to develop large reserves of strippable coal.

A group of 15 modern prospectors from Tennessee has arrived in Alaska for the purpose of uranium prospecting. They are reportedly very well equipped and have technical persannel among them. Presentiy based at Willow lake on the Richardson Highwey, they have plens for otber speciflc areas in the Third and Fourth Divisions as snow conditions permit. Aerlal work will also be done.

Prospectors Outfitters, Inc. is a new concern in Anchorage which will operate a retall store catering to prospectors and supplying all prospecting needs. 
FOURTH DIVISION - Geochemical research is belng carried on at an accelerated pace at the University of Alsska during the sumer. A simplified fleld procedure for tungsten has been worked out, and research on other geochemical projects is underway.

\section{OILI NEWS}

Drilling will be under way shortily near Goose Bay, across Kulk Arm from Anchorage, by the Alaska Gulf 011 and GasiDevelopment Company. A r/6upoot rlg capable of driling to 6000 feet arrived in Anchorage by barge and is now being moved to the drill site.

Anchorage Gas and 011 Development, Inc, is also importing a rig for drilling at Eouston, 30 miles north of Anchorege. When assembled, the rig weighs 86 tons, hes a 126-foot derr1ck, and a 10,000-foot drilling cepecity.

Department of the Interlor 18 asking the views of four Congressional comittees on the possible opening of the lands adjacent to the Pet 4 reserve that were withdraw by Executive Order 8 ? during the war. The Navy has advised that it has no objection provided there is no effect on the original pet 4 land. The oil land beling sought by private enterprise amounts to about 24 milifion acres.

Oil well drillers may be interested in the following speciflcation and prices on barite for drilling mud quoted by the Yuba Milling Company, 1069 Becond Street, Berkeley 10, California: Minimum of 4.2 specific gravity, groind to $95 \%$ through 325 mesh, FOB San Francisco port $\$ 30.50 /$ ton and Seattle port $\$ 10.50 /$ ton in 50 ton minimum shipments. \$2/ton extra if maxine bags are used.

\section{INFORMATION FOR URANIUM FROSPECTORS}

The TDM has been somewhat concerned over two facts, namely, that most ore minerals of urantum are known to be quite soluble and thus readily leached from surface outcroppings, and that the majority of the world's known uraoium alscoveries have occurred in aria, or geml arld, regions. Recosnizing these points, we've been watching the uranium prospacting activities in the heavy rainfall belt of Southeastern Alaska very carefully, hoping to get some clue that would answer the question "Will surface leaching in regions of excessive rainfell completely remove the uranium minerals and thus minimize chances for discovery with radiation detection instruments?"

Having now had the opportunity to investigate three prospects in the "rain-belt" we are satisfied that there 1s. no further need for concern on this score. While some leaching undoubtedly does occur it is by no means complete. It constitutes no serious problem to prospecting with counters, cither afield or airborne.

Samples taken at the surface of three widely separated prospects, in the region under conslderation, revealed uranium contents ranging from very low grade up to a high of two percent. Two contained primary minerals within a foot or so of the surace and the other khowed no primary mineralization but a pronounced development of the secondary minerals usually derived therefrom. At the surface of each of these prospects counter readings were found to be cormensurate with the grade and volume of the material. Two of the showlngs were digcovered by reconnaissance afoot, using single GM tube counters. The third, by a multiple tube airborne instrument flylng 100 to 200 feet above the ground. 
We hope to be able to publish a geological and mineralogical description of the newly discovered Ross-Adams deposit in our next 1ssue. ThIB information cannot be released at the present time.

\section{USGS ACTIVITIES}

The U.S. Geological Survey has publlshed several open-file reports lately which will be of interest to prospectors. Among them are the following: "Geocherical Exploretion for Antimony in Southeastern Alaska" and "Geology of Two Areas of Pegmatite Deposits in Southeastern Alas'sa" by C.L. Seinsbury, "Phosphate Deposits in Northern Alaska" by W.W. Patton, Ir., "Notes on a Coel Deposit on the Beluga RIver, Alaska" by F.F. Barnes, and "Preliminary Geologic Evaluation of the Chena Area, Aleska" by Jobn R. WIlliams. These reports can be seen in the USGS offlccs at Juneau, Anchorage, and College, and at the Juneau TDM office.

The USGS reports that they 1 lew 10,000 miles of aeronagnetic traverses in Alaska last year, meinly across sedimentary basins to determine possible favorable petroleum structures. Ground mopping will follow in areas where the aerial survey indlcates such possibllities.

\section{ASBESTOS}

A half dozen or more minerals are marketed as asbestos but broadly speaking they fall into two classifications, chrysotile and amphibole. The first is a fibrous serpentine of the composition $\mathrm{H}_{4 \mathrm{Mg}} \mathrm{O}_{\mathrm{g}}$. It $1 \mathrm{~s}$ characterized by the fineness of the fibers, sileiness, and high tensile strength. The amphibole asbestos is usually too harsh for spinning but is more resistant to heat and to acids. In this cless is tremolite asbestos $\mathrm{CaMg}_{3}\left(\mathrm{~S}_{3} \mathrm{O}_{3}\right)$.

Asbestos was known in Alaska in pre-historic times and has been found in excavations on anclent village sites between Shungnals and Kiana on the Kobuk River, the same area within which it is now beginning to be mined. Its presence on Dahl Creek was noted as early as 1910 but as the floer was then judged unsuitable for spinning no further attention was paid to it until 1931 when Irving Reed of the Territorlal Department of Mines visited the region. Fe sent to the burcau of Mines at Washington saxples of chrysotile asbestos of high quality. Later, as part of the search for the strategic minerals, both Territorial and Federal engineers and geologists examined the area in 1943 and 1944, and the work of the Bureau of kines was continued into 1945 .

The Kobuk River asbestos diatrict 18 about 300 miles northeast of Nome or 150 miles eagt of Kotzebue on Norton Sound. It is easily accessible by plane or by river boat from Kotzebue. The deposits are found in a range of mountain parallel Ing the river and some 10 to 20 miles north of it. These are known as the Cosmos Eills at the east and Jade Hilis at the west. The district is about 45 miles long from east to west and extends from the Kogoluktuk River to Jede Creek. The Cosmos Hills rise to about 2,000 leet, but the Jade Hills are higher. The range is cut by a number of southvard-flowlng streams-Kogoluktuk River, Dahl Creek, Wesley Creek, Camp Creek, Cosmos Creek, and Shungnak River..flowing across or out of the Cosmos Hills and Ambler River, Redstone River and Jade Creek cut through Jade Hills. The mountain msss consists of ancient sediments, graywackes, and limestone, now represented mainly by schlst. These rocks were intruded by an uztrabasic rock, presumably a peridotite but now mass of serpentine. In the Cosmos H1lis the serpentine seems to be a sill resting op the metamprphic rookg. In this sempentine, both chrysotile 
and tremolite asbestos has been found in the form of velniets of cross fiber and as slip fiber along planes of movement. The surface is mach covered by talus, and only small patches have been uncovered, but float asbestos is widespread. Jade is also found, in one place as a veinlet in asbestos but malniy in the form of large boulders of float. Though the Kobuk asbestos is the best known so far, otber deposits are fairly widenpread throughout Aleska. A deposit on Bear Creek, Admiralty Islanã, hes been known for meny years. A large deposit has been reported to exist north of the Yukon River in the viclnity of Rampart. A new esbestos deposit in the Mentasta Pass area was located in 1954. A deposit in the Hyder district has been optioned. Samples of esbestos, mostly of poor grade, are sent into the TDM assay office quite often from nearly all perts of Alesica.

Some of the physical properties that good asbestos must possess for varlous uses are as follows: good flber length; good flexibility; fine fibers; silkiness; hlgh tensile strength; resistance to acids, sea water, moist alr, and heat; and good "spinnability". Flbers 1/4 inch or more in length and otherwtse of good grade are of comercial interest. The quality of asbestos may be easily determined by a few olmple tests. Visual inspection will determine length, color, silkiness, fineness, etc. Fiber can be separated by rubbing and crushing between the fingers. Single Iibers may then be tested for flexibility and tensile strength. Several flbers may be twisted together, forming a yarn, to further check for strength and flexiblifty. Fibers should not be fusible with a blowpipe.

Price quotations for various grades vary from $\$ 35$ to $\$ 1500$ per ton. However, since prices and grades vary so widely in different localities, market quotations can te used only as a general guide. In actual practice, the prospector should submit samples of his asbestos to the various purchasers (of which there is a long ist) and determine where be can get the best finencial deal. (The first two paragraphs of tbis article were talsen fram Bureau of Mines Information Circular No. 7379).

\section{E. AND M. I. METAZ MARKET PRICES}

\begin{tabular}{|c|c|c|c|}
\hline & $\begin{array}{l}\text { June 23, } \\
1955\end{array}$ & $\begin{array}{l}\text { Month } \\
\text { Ago }\end{array}$ & $\begin{array}{l}\text { Year } \\
\text { Ago }\end{array}$ \\
\hline $\begin{array}{l}\text { Copper, per lb. } \\
\text { Lead, per Ib. } \\
\text { 2inc, per Ib. } \\
\text { Tin, per lb. } \\
\text { Quicksilver, per flask } \\
\text { Silver, foreigh, New York } \\
\text { Silver, domestic, per oz. } \\
\text { Platinum, per oz. } \\
\text { Nickel, per Ib. } \\
\text { Molybdenum, per lb. } \\
\text { Tungsten ore, per unit } \\
\text { Titantum ore (ilmenite) . }\end{array}$ & $\begin{array}{l}35.7 \phi \\
15 \phi \\
12-1 / 2 \phi \\
94-1 / 2 \phi \\
\$ 281-283 \\
89-1 / 4 \phi \\
90-1 / 2 \phi \\
\$ 78.80 \\
64-1 / 2 \phi \\
\$ 3 \\
\$ 63 \\
\$ 20\end{array}$ & $\begin{array}{l}35.7 \phi \\
15 \phi \\
12 \phi \\
91-3 / 4 \phi \\
\$ 300-302 \\
90-1 / 4 \phi \\
90-1 / 2 \phi \\
\$ 76-79 \\
64-1 / 2 \phi \\
\$ 3 \\
\$ 63 \\
\$ 18-20\end{array}$ & $\begin{array}{l}29.7 \phi \\
14 \phi \\
11 \phi \\
94-3 / 4 \phi \\
\$ 275-280 \\
85-1 / 4 \phi \\
90-1 / 2 \phi \\
\$ 84-87 \\
604 \\
\$ 3 \\
\$ 53 \\
\$ 18-20\end{array}$ \\
\hline
\end{tabular}

